\title{
The Building of Bell-Towers Added to Romanian Churches
}

\author{
A Pattern of Intercommunity Cooperation in the Religious Life \\ of the Romanians and the Saxons from Sibiu County, \\ in the Eighteenth and the Nineteenth Century
}

\author{
IOAN Ovidiu ABRUdAN*
}

\begin{abstract}
This paper aims to emphasize a specific aspect in the evolution of the architecture of churches built by Romanian Orthodox or Greek-Catholic communities in the Sibiu region, in the second half of the eighteenth century and during the nineteenth century. More exactly, it is the widespread presence, in the ecclesiastical architecture of that county, and also in other Romanian Transylvanian settings, of the western tower, added to the church, which housed the bells and sometimes even clocks. In most cases, the raising of these towers was entrusted to Saxon masons from Sibiu, whose names have been preserved in inscriptions on the walls of edifices, or by their registering in contracts signed by the Romanians who ordered the execution. The involvement of those worthy craftsmen represented an important factor in maintaining the dialogue and cultural exchanges between the two communities that lived together in the Sibiu County region.
\end{abstract}

Keywords: church architecture, bell-towers, western tower

Impressed by a visit to Sibiu, during a trip undertaken in the early years of the sixteenth century, in the lands to the north of the Carpathian arc, and further to Hungary and Austria, Neagoe Basarab, who in the meantime had become ruler of Wallachia, subsequently ordered, probably in 1517 , to Johann and Celestin, two famous goldsmith masters from the fortress on the Cibin River, several pieces of silverware, including a censer, which reproduced the shape of a church tower he had seen in Sibiu. It was the big bell tower of "Saint Mary" Catholic Church, which had just been raised in $14999^{1}$, of which Neagoe said: "we visited the entire Hungary and nowhere had we seen a more beautiful tower" ${ }^{2}$. We can imagine the overwhelming feeling, in the face of the massiveness and height of the Gothic tower, experienced by the traveler familiar with the rather low, Byzantine architecture of Wallachian places of worship. The pious ruler, later canonized by the Orthodox Church - which

\footnotetext{
* Ioan Ovidiu Abrudan, PhD, Lecturer at the "Andrei Șaguna” Faculty of Orthodox Theology, "Lucian Blaga” University of Sibiu, Romania. Address: Str. Mitropoliei 20, 550179 Sibiu, Romania; e-mail: abrudanioanovidiu@yahoo.com.

1 Vasile Drăguţ, Arta gotică în România, Bucureşti 1979, p. 41.

2 Grigore G. Tocilescu, Biserica episcopală a Mănăstirii Curtea de Argeş restaurată în zilele $M$.

S. Regelui Carol I. Sfinţită din nou în ziua de 12 octombrie 1886, p. 40.
}

RES 8 (1/2016), p. 9-26

DOI: $10.1515 /$ ress-2016-0002 
acknowledged, among his numerous virtues, the merit of having founded one of the most beautiful churches ever built by the Romanians - had a refined aesthetic sense; his openly expressed admiration for Transylvanian Gothic architecture was a testimony of his interest in the civilization that flourished in the foreign, though geographically adjacent universe of Saxon burgs. Such magnificent buildings, along with other remarkable achievements of the Saxons in the fields of art and craftsmanship, had always been admired by the Transylvanian Romanians who, next to them and by a mutual transfer of values, were giving shape to the destiny of their own civilization.

The architecture of old Orthodox wall churches of Sibiu is an eloquent testimony that facilitates the understanding of this continuous symbiosis of cultures and civilizations that occurred despite the state of adversity, often of conflict, that characterized relations between ethnic communities that lived next to one another in this part of Europe. As specific elements of ecclesiastical architecture, the bell-tower added to the west end of the church, rarely short and robust, often high and thin, ending with the spire raising boldly towards the sky, used to be a reason of pride for Saxon village communities, which were always in competition. The Transylvanian Romanians'striving, obvious throughout history to affirm their dignity as similar to that of other ethnic groups, seems to be the most natural explanation for their adopting such architectural forms, bearing a high symbolic value, which were not part of the Romanian tradition in most Orthodox and Greek Catholic churches that were built after the promulgation, in 1781, of the religious tolerance edict by Emperor Joseph II and up to the Unification of 1918. The year 1781 may be considered a chronological landmark, as the new religious architectural form became frequent ever since both in the Sibiu County region and everywhere else in Transylvania, although churches built of stone and brick, a more stable alternative to traditional churches made of wood, had been raised before that date. But the presence of the bell tower was exceptional in the case of Romanian churches built before 1781. In the Sibiu region, one can identify only extremely rare cases of such elements, exceptions in this respect being, for instance, the tower built in 1757 at the church of Sadu, or that of the church from Sebeşul de Jos.

It is therefore reasonable to think that the increasing number of Romanian wall churches, as well as the raising of towers on the west end of those monuments, were the result of the promulgated edict of religious tolerance. The decree stipulated that all citizens of the empire were allowed, irrespective of their religious belonging, to raise wall churches, and equip them with bells, 
if the village community included at least 100 families $^{3}$. However, this was not the only condition to be met by the Romanian communities, as a diploma promulgated by the sovereign on September 3, 1783, stipulated that the subjects of Orthodox confession had the obligation to support, from their own contributions, their priests, churches and the confession, without receiving any „support from the state or the other religions”. It was a discriminatory measure that affected especially the Orthodox from Sibiu who, in the course of history and by various decisions of authorities, were asked to contribute with money and labor to the erection and maintenance of Saxon churches and religious schools, in those places where Romanians were considered to be only tolerated. That was the case, for instance, of Avrig village, which in 1582 had received from the Sibiu magistrates a set of rules of coexistence, to be observed by the community with mixed ethnic composition. The fifth rule, for instance, stated that "while two nations live in Avrig, namely the German and the Romanian community, when a church, school or rectory (for the members of the Lutheran confession), must be built, both nations should help, the Romanians bearing half of the obligations. If they refused, the fine was a silver mark" 5 .

Another measure adopted by the authorities in order to temper the initiatives of Orthodox communities to raise churches, after the edict of religious tolerance had been issued, referred to the tighter control over the support traditionally offered to the Transylvanian Romanians by princes and boyars from Wallachia. Responding to Emperor Joseph II, in January 1782, in connection to the issue of attracting Romanians at the Union with the Church of Rome, Bishop Petru Pavel Aron, from Blaj, showed that one of the obstacles that had to be immediately removed, with the view of promoting the new faith, was represented by the close ties of the Orthodox clergy in Transylvania with the transalpine principalities and the ease with which the Habsburg authorities allowed "the Orthodox to build other churches to replace the ones taken" and assigned to the Greek-Catholic Church ${ }^{6}$. In this way it was intended that

3 Ioan Lupaş, Istoria bisericească a românilor ardeleni, Sibiu 1918, p. 125, 163; idem, "Contribuţiuni la istoria românilor ardeleni (1780-1790), cu 84 Acte şi Documente inedite, culese din Arhivele de la Viena, Budapesta, Sibiu şi Braşov", in: Analele Academiei Române, series II - vol. XXXVII/1914-1915, Bucureşti 1915, p. 610.

4 Josef Heinrich Benigni Edler von Mildenberg, Handbuch der Statistik und Geographie des Großfürstentums Siebenbürgen, vol. II, Sibiu 1837, p. 50, 51, apud, Paul Brusanowski, Pagini din istoria bisericească a Sibiului medieval, Cluj 2007, p. 235.

5 Ştefan Lupşa, "Satul lui Gheorghe Lazăr", in: Mitropolia Ardealului, Sibiu 7-8/1962, p. 494.

6 Virgil Ciobanu, "Statistica Românilor ardeleni din anii 1760-1762”, in: Anuarul Institutului de Istorie Naţională III/1924-25, Cluj 1926, p. 619-620. 
finding the means to build churches and schools should be the responsibility of village communities, without any external support.

However, material deprivation was not the only difficulty encountered by the Transylvanian Romanians as regards the raising of worship places. Before 1848, the sons of serfs were denied access to learning any trade and to entering professional corporations. Therefore there were no Romanian craftsmen affiliated to the guilds of carpenters, masons and painters. Where, exceptionally, a Romanian managed to break through such obstacles, as it happened in 1771 with Marcu, the son of a serf in Colun, who learned the craft of masonry, the condition of being accepted into the guild forced him to practice his craft elsewhere than in territories where the Saxons lived ${ }^{7}$.

However, by simply taking into account the considerable number of churches, with walls of stone and brick, which had been built before, but especially after the edict of religious tolerance, it appears that the Romanian communities had found solutions to overcome the difficulties they encountered in supporting such complex undertakings. Even if the information in this respect is scarce, it can be assumed that the pace at which several dozens of new edifices appeared, built in a relatively short period of time, was the effect of the commitment on the part of both the Orthodox and the Greek-Catholic Transylvanian church hierarchy to support such an initiative.

An argument in this respect may be considered the unity of style that characterizes religious buildings of that period: namely the choice, in most situations, of a planimetric and structural style which reproduces architectural elements characteristic of the south Carpathian region, that became widespread in Transylvania during the eighteenth century, when boyars and rulers from Wallachia built several worship places there. Such specific elements (i.e. the rectangular plan of the nave, ending on the east with an apse unhooked, semicircular inside and polygonal on the outside ${ }^{8}$, and the system of vaulting the nave, and sometimes also the narthex and the eastern apse, with cupolas supported by semicircular arches) may be recognized in the group of churches erected after the edict of tolerance had been issued. However, the defining feature for the architecture of Transylvanian places of worship of that period remains the widespread presence of the bell tower, containing either bells or clocks, and usually located on the west side of the building.

\section{Lupaş, Mitropolitul Andreiu Şaguna. Monografie istorică, Sibiu 1911, p. 174.}

8 Towards the beginning of the nineteenth century, in the case of the Romanian churches built in Sibiu and its surrounding villages (as, for example, Sadu, Răşinari, Boiţa or Bungard) that type of Byzantine apse was replaced by a the one with a large diameter, a Romanic element present in and adopted from Saxon models, which seems to be unhooked and semicircular, in both the inner and the outer side of the building). 
There is no doubt that the Transylvanian Romanians were inspired by the architecture of Saxon churches in equipping their own places of worship with bell towers. This element can be identified even in the most ancient basilicas built by the Saxons in the style of Western Romanesque architecture, the churches being provided with one or two massive towers, either from the outset, or after the devastating invasion by the Mongols, in $1241^{9}$.

The typical form of the West tower in Transylvania can be observed in the Saxon fortified churches from Cisnădie and Cincu, or the ones erected later, in Cristian, Avrig, Săcădate, Şomartin and Hosman ${ }^{10}$. With a manifestly defensive function, but also being a symbolical representation of a certain privilege, church towers actually took the model of fortress towers that used to be residences for the nobles of the region ${ }^{11}$. Such association emphasizes the important role assumed by the nobles in guiding the first groups of Saxons to the settlements of colonization, alongside the encouragement to build churches with solid walls and a monumental aspect, in order to awaken the self-consciousness of the communities these nobles lead. At the same time, it was an expression of the close ties the Saxons preserved with their places of origin $^{12}$, some evidence in this respect being the similar aspect of early Romanesque and Gothic towers which they built for their churches in Transylvania, beginning with the mid-thirteenth century and those from the second half of this century, with the architecture of strongholds of castles in Germany ${ }^{13}$.

Typically the square ground floor of towers had cross vaults and communicated, via one or more openings, with the nave. Above it, there were sometimes up to four overlapping levels, accessed by stairs placed inside the walls, which further emphasized the fortified character of the building, together with the narrow firing windows, opening in the thick walls of the upper floors. However, the presence of the higher and wider biforis/bilobed top floor windows has been associated with the "cultic function of the tower, as the toll of bells had to propagate properly" 14 . Above the last defense floor of the tower there were pyramid-like spires whose height and shape changed during the various stages of historical development.

9 Hermann Fabini, Universul cetăţilor bisericești din Transilvania, Sibiu 2012, p. 44.

10 Ibidem, p. 61.

11 Ibidem, p. 44.

12 Ibidem, p. 37.

13 Ibidem, p. 63.

14 Ibidem, p. 62,63. 
The architecture of these towers became increasingly monumental when, during the period of Gothic architecture flourishing in Transylvania, starting in the second half of the fourteenth century and continuing up to the first quarter of the sixteenth century, the Saxon rulers in major Transylvanian cities initiated the construction of splendid parish churches ${ }^{15}$.

It is important to point out here that, in the southern part of Transylvania, one can identify a first period of synchronization as regards the architectural style of Romanian and Saxon churches. Counting among the oldest stone monuments built in the late Romanesque style by princely families or by Romanian Orthodox communities in Ţara Haţegului, the churches from Sântămărie-Orlea and at Strei (both in Hunedoara County), the former raised between 1270 and 1280, while the latter dates back to the 1300s or the beginning of the fourteenth century ${ }^{16}$, "are indicative of the preference for the bell tower added to the west side" 17 . As regards the church from Strei, archaeological investigations established the fact that the bell tower, the rectangular nave and the altar belong to the same phase of construction"18

A tower on the west side was later added to the stone church from $\mathrm{Gu}$ rasada (jud. Hunedoara), which has a polilobated central plan of Byzantine influence, and was also built in the thirteenth century. Massive bell towers can also be seen next to the churches, built in the thirteenth century, from Ribiţa (Hunedoara county), and Râmeţ (Alba county). The princely church from Cetatea Colţului (Hunedoara County) illustrates a particular type of ecclesiastical monument, still prevalent from as early as the late 12 th century, among Transylvanian noble families. Its tower house has three floors above the altar and dates back to the $1300 \mathrm{~s}^{19}$.

As we have already mentioned, the oldest existing Romanian church tower from Sibiu County can be found in Sadu. The church to which it belongs, currently Orthodox, dedicated to "Assumption of the Virgin Mary" is the result of a rebuild, on the foundations of another older church, conducted in the eighteenth century, by the congregation of Greek-Catholic worshipers, with significant support from the future Bishop Ioan Inochentie Micu, who

15 Ibidem, p. 48.

16 Radu Popa, La începuturile Evului Mediu românesc. Ţara Haţegului, Bucureşti 1988, p. 232, 234.

17 V. Drăguţ, Arta gotică, p. 31.

18 R. Popa, La începuturile Evului Mediu românesc, p. 234.

19 Ibidem, p. 239. 
was born in that village. Therefore the place of worship to which we refer replaced another one that existed before in the cemetery, where graves older than the church itself can still be found ${ }^{20}$. The church "was built in 1720, from the desire and with the effort of Dumitru Dikoe and priest Toma, who did not have enough money, but managed to finish it using the 300 florins taken from Gaudila (probably Gândilă) Stroia. Two hundred florins were given by villagers, who themselves worked to raise the building, while the towers and the big bells were paid by the benefactor Bishop [Inochentie] «Huius autem turis et maioris campanae benefactor est ill[ustrissi]mus d[omi] nus baro Klein episcopus Fogarasiensis unitus...»)"21. The sum of 200 florins given by villagers of Sadu apparently represented a loan without interest obtained, in 1720, from a certain Andrei, a Serbian from Wallachia, with the specified purpose of restoring the church ("ad reficiendam beszerikam") 22 . About priest Toma, there is no other detail besides the fact that he was no longer mentioned among either the Orthodox or the Greek-Catholic priests registered in Sadu, in the conscription acts of Bishop Klein, in 1733.

The building, with massive brick walls, appears as a rectangular nave, completed eastwards with an unhooked apse, of semicircular section. The interior, divided according to Eastern liturgical rites, has all the characteristics of ecclesiastical architecture from the south of the Carpathians, the nave being covered with a dome on pendants and the narthex with cross-vaults. After this stage, the nave was extended towards the east, by the interposing of a bay between it and the new apse of the altar ${ }^{23}$.

We do not know how we should interpret the information to which we referred above, namely the fact that even before it was consecrated, in 1729, the Greek-Catholic Bishop of Alba Iulia and Făgăraş, Ioan Inochentie Micu, had contributed to the building of Sadu church "towers" and equipped them with "the big bells". For it is still difficult to assume that the church was designed with not only one, but two towers ${ }^{24}$. But we have the certainty

20 In 1719, the tradesman Ilie Cujmăreţ, born in Kiprovaţ village, south of the Danube, was buried north of the current church.

21 Greta Monica Miron, „...poruncește, scoală-te, du-te, propovedueşte...”. Biserica grecocatolică din Transilvania. Cler şi enoriaşi (1697-1782), Cluj-Napoca 2004, p. 329, note 189.

22 Friedrich Schuller, "Zwei Konskriptionen des einstigen Hermannstädter Stuhles aus dem Beginne des 18. Jahrhunderts", in: Sozial-und Wirtschaftsgeschichte "Allgemein» Siebenbürgisches Steuerwesen, Staatssteuer, IV.4, vol. A 32/ 1903, p. 88-202.

23 Marius Porumb, Dicţionar de pictură veche românească din Transilvania, sec. XIII-XVIII, Bucureşti 1998, p. 344.

24 The two towers that can be admired today on the western side of the Greek-Catholic cathedral, built by Bishop Inochentie in Blaj, in 1756, were added to the church only in 1838 . 
that the current bell tower was erected in 1757, therefore one year after the appointment of a new bishop in Transylvania, in the person of Petru Pavel Aron, as indicated by an inscription left on a brick mounted in the north wall, that mentioned the name of the man who led the work, "mason Oprea from Făgăraş".

What drew the particular attention of Virgil Vătăşianu, a specialist in ancient art history, was the nature of the décor executed on the facades of that massive bell tower. The ornamentation, the outline of which was performed with bricks that remain apparent against the plaster, is visible above the ground floor, the tower being "surrounded by a Wallachian girdle over which two registers composed of circles intersect; above it there is a register of blind arcades. The decor is exceptional, but a confrontation with the Brâncoveni Monastery belfry and the facade of the church of Mogoşoaia explains the origin of these motives, but which were reinterpreted by the mason from Făgăraş, who thus managed to create an exceptionally festive façade" 25 . Therefore, the historian connected the experience of that Romanian mason (whose origin was not transalpine, but from Transylvania, as indicated by the character of his name) with the evolution of the architectural décor of church facades from Wallachia, during the Brancovenian epoch. If, as indicated by his intervention in Sadu, mason Oprea was familiar with the spirit of the Wallachian art of the time, by the simple fact that he was born in Făgăraş, (that is an inhabitant of a city that had not only a Brancovenian church, but was situated in the geographical proximity of another monument, raised by the same founder, the church from Sâmbăta de Sus Monastery), he also demonstrated the need to naturally integrate the element that was foreign to the Romanian tradition, namely the western tower, into the architectural ensemble of the church. The same concern, but with a different solution, will be encountered in the case of the tower of "St. Paraskevi" church from Răşinari.

At Sadu, probably due to the passage through the village of Emperor Joseph II, in 1788, the church came into the possession of the Orthodox community, which eventually regained its majority. Towards the end of the eighteenth century, its members undertook new interventions of repairing and refurbishing the place of worship, among which a cant of the tower was probably performed (in 1795, according to the inscription on the southern side of the building, just below the cornice) involving, besides the equipment with a clock, also a remodeling of the helmet that took over a complex form

25 Virgil Vătășianu, "Arta în Transilvania de la începutul secolului al XVII-lea până în primele decenii ale secolului al XIX-lea", in: Istoria Artelor Plastice în România, vol. II, București 1970 , p. 176. 
of baroque inspiration ${ }^{26}$. As we shall see later, the operation seems to have followed closely the model of the change that the tower of the church in Raşinari underwent, the two monumental belfries ending up quite similar.

As already stated, there is another tower of a Romanian church in the Sibiu region, besides the one we have just referred to, which was built even before the promulgation of the edict of religious tolerance. It's raising, as it happened in the case of the church for which it had been built, was possible by the chance that the respective parish was assigned to the Greek Catholic deanery of Sadu, which had a privileged position, as we have seen, during the period of Bishop Inochentie Micu in Transylvania. The latter allowed the parishes under that ecclesiastical jurisdiction to initiate collections for raising the funds needed to build churches of stone and brick. Thus, as Greta Monica Miron has pointed out, "the Greek-Catholics from Sebeşul de Jos benefited from such a right and managed to raise a church in 1738, helped by the Greek-Catholic priest Coman" 27 . The building of the worship place seems, however, to have lasted longer, since the text of the inscription shows that the works were completed only in 1741, the probable year of consecration, "and the tower [was completed] in the year 1770"28.

In Sibiu, the Greek Catholic Church, also known as Church "Among the Fir Trees", whose cornerstone had been laid in 1778, by Bishop Grigorie Maior, was completed, again with the significant support of Empress Maria Theresa, only after the issuing of the religious tolerance edict, being consecrated in $1784^{29}$. The western façade of the church, designed in the spirit of Baroque architecture, is marked on the median axis of the robust tower, the erection of which above the narthex was not completed until $1788^{30}$. During the execution of the construction, the commissioners had to face the protest of the builders' guild in Sibiu, discontent that the work had not been entrusted to them, but to masons brought in from elsewhere ${ }^{31}$.

At the middle of the eighteenth century, there was a Greek-Catholic deanery in Răşinari. All Greek-Catholic bishops had served at the altar of its

\footnotetext{
26 The helmet is made up of a pyramidal base, over which there are two entire bulbs, between which a lantern is being intercalated.

27 G. M. Miron, Biserica greco-catolică, p. 329, n. 188.

28 M. Porumb, Dicţionar de pictură veche, p. 364.

29 Teodor Bodogae, "Sibiul, vatră de vieţuire ortodoxă românească”, in: Arhiepiscopia Sibiului-Pagini de istorie, Sibiu 1981, p. 17.

30 Şematismul veneratului cler al Arhidiecezei Mitropolitane Greco-catolice de Alba Iulia şi Făgăraş pe anul Domnului 1900, de la Sfânta Unire 200, Blaj 1900, p. 561.

31 Aurel Radu, "Biserica dintre brazi”, in: Telegraful Român, 107(39-40/1959), p. 3.
} 
very old church, starting with Atanasie Anghel. Being too small and affected by the passage of time, the worshipers, led by Archpriest Tatomir, decided to replace it with a new place of worship, more appropriate for the higher ecclesiastical ranking acquired by the village. Bishop Petru Pavel Aron himself served during the ceremony of laying the foundation stone, and "sent the archpriest of Sadu to hire architect ... gave money for the foundation and paternally advised those who initially hesitated, and raised a wonderful church" 32 .

The site was opened on the $5^{\text {th }}$ of July 1753 when the bricklayer, the Saxon Johann Dortlich of Sibiu, whom the village community had contracted to undertake the work, started the demolishing of the old $\operatorname{church}^{33}$. The work of building the new church lasted until 1755, "the tower, originally shorter, being most likely added in 1758 "34, if we consider the inscription on the southern side of the belfry. The fact was demonstrated by the document found in the canopy that existed above the communion table of the church in Răşinari published by Emilian Cioran in 1940, including the thorough report, prepared by the Orthodox archpriest ${ }^{35}$ Sava Popovici, in 1795, concerning the nature and costs of the work done in the church, between the years 1787 and 1795 and which were meant to complete the artistic entity of that impressive monument. The document also mentioned, among others, that "in 1789, the village leader Coman Şerb and «all the six priests " concluded a contract with the skillful Mihail Betzinger from Sibiu «to raise the spire of our church on a place higher than it is now and cover it with tin roof and at the same time to make the cross on the tower from the same expenses and be 8 feet high»" 36 (this measurement appared as such in the cotation) and further, taking up the same issue, it communicated that "the tower was raised in 1789 and 800 florins from the ones belonging to the village were spent" ${ }^{37}$ and "for the clock placed in the church tower 420 florins were spent" 38 . A concise description of the architectural features of the church bell tower of "St. Paraskevi” church was made by Florica-Saveta Pop, the researcher who identified the model that inspired, it seems, the architects in its design. "The Bell tower,

\footnotetext{
32 G. M. Miron, Biserica greco-catolică, p. 336, 337.

33 Emilian Cioran, "Biserica cu hramul Cuvioasa Paraschiva din Răşinari”, in: Omagiu Înalt Prea Sfinţiei Sale Dr. Nicolae Bălan Mitropolitul Ardealului, la 20 de ani de arhipăstorire, Sibiu 1940, p. 325.

34 Ana Dumitran, Iacov zugravul, Alba Iulia 2010, p. 112, note 37- 41.

35 The church had been given back to the Orthodox in Răşinari before 1760 .

36 E. Cioran, Biserica cu hramul Cuvioasa Paraschiva, p. 328.

37 Ibidem, p. 334.

38 Ibidem, p. 335.
} 
adossé (this word appared as such in the cotation) to the edifice, has an opening on three sides. The interior pavement was made entirely of stone slabs. It seems that the prototype was the Jesuit Church in the Great Square, Sibiu, built between 1726 and 1733, itself a copy of Schottenstift Viennese church, completely rebuilt in the fifth decade of the eighteenth century" ${ }^{39}$.

Returning to the statement made before, regarding the concern of the masons of the church in Sadu for a more natural integration of the Western architecture of the bell tower in the entire aspect of a building that had to show, however, the features of Eastern and Orthodox spirituality. Their solution consisted of the application of a decoration on the walls of the tower that interpreted the specific ornaments of Brancovenian churches. We can see that the craftsmen of "St. Paraskevi” church of Răşinari faced a similar challenge, though they adopted a different solution. It was represented by the combination, in decorating the facades, of the architectural technique (through blind arches and holes) with monumental painting, the figurative representations forming a rich and very attractive iconography whole. The effect obtained is spectacular "the entrance tower walls looking like the folio of a manuscript, adorned with miniatures" ${ }^{\prime 0}$. The painter, Popa Ioan Grigorievici, left his signature on the segment of the fresco that contains the scenes depicted on the vault and arches under the tower, indicating the year when these were executed, namely 1785, and that he was the nephew of "Ranite from Campulung", a famous painter, as he was among the craftsmen that worked at the Brancovenian site of Hurezi monastery. The images were painted on the south and west façades of the belfry, awarded to the same Ioan Grigorievici, were probably painted at the same moment, or at a date close to it. We know that they have been registered and paid separately, as shown by the report written by archpriest Sava Popovici ${ }^{41}$.

Within the span of only one decade, in Sibiu, albeit not inside the city, but beyond its walls, in the suburbs of the town inhabited by the Romanians, the so-called măierimi, one from the gate towards Ocna and one from the gate towards Cisnadie, two Orthodox churches were erected, both with bell towers of overall dimensions exceeding 30 meters. Their style was inspired by the Austrian architecture of Joseph II's era, the characteristics of which are linked to the very slenderness that gives the belfries the pronounced sharpness of pyramid shaped spires built on octagonal bases, the ellipsoidal openings from

39 Florica-Saveta Pop, "Pious Paraschiva Church from Răşinari - Interior and Bell Tower Painting”, in: Brukenthal Acta Musei, Sibiu/Hermannstadt, VI.2/2011, p. 345, 346.

40 E. Cioran, Biserica cu hramul Cuvioasa Paraschiva, p. 333.

41 Ibidem, p. 335 
the tower walls as well as the semicircular form of the eastern apses, with a diameter extending to be almost similar with the breadth of the nave. The same features indicate the idea, yet unconfirmed by documents, that the craftsmen employed were representatives of the guild.

The first of the two Romanian places of worship was built in 17881789 by Stana Petru Luca, in the Josephine district, but was demolished because of the damages caused by the earthquake in 1802 and rebuilt from the foundation in the same year. Meanwhile in 1791, the church dedicated to "St. Luke", in another Romanian suburb of Sibiu, had been raised.

To the same group of church buildings, raised in the style of the era of Joseph II, with towers that seem to compete as regards the supple aspect of their body and the arrow-like sharpness of tile roofs, belong a few other churches, built in villages nearby Sibiu, by members of the Orthodox or the Greek Catholic parishes. The Orthodox Church in Poplaca (1793) was done, as certified by the inscription on the wall of the enclosure, by a certain George Bezengăr (Beztzinger - possibly related to mason of Sibiu Michael Betzinger, who was working, at about the same time, in Răşinari). The "Holy Trinity" Orthodox Church of Sibiel was built, according to the inscription on the beams above the entrance door in the narthex, in 1765, but the tower, one of the most beautifully proportioned from among the ones in existence in this part of Transylvania, was added to the construction only later on. An inscription noted in the plaster of the wall, on the inside, under the bells, speaks about that fact: "Founder Oprea Săroi being leader, the towers were built on Oct. 24. 1794 ..." Also in 1794 with the permission of Emperor Joseph II, as confirmed by local tradition, and also with a certain delay, the church tower in Cacova (today Fântânele) a village near Sibiel was built, a building that dated from the year 1771. In the village of Galeş, the building of the tower was completed eleven decades after the raising of the church, upon which construction had already begun in 1700. An inscription communicates that fact, signed by the Saxon craftsman who executed the work: "haben angefangen 1700-1809 Maurer Nösinger Maister”.

A different typology, as compared to the edifices we have just described, is present in the case of a smaller number of bell towers, built in villages situated at the foot of the Fagaraş Mountains, on the left bank of the Olt at the end of the eighteenth century and during the first three or four decades of the next century. An unexpected reinterpretation of elements of medieval Roman-Gothic architecture was achieved in their case, characteristic of the places of worship built by the Saxons soon after their settlement in Transylvania. One such example is represented by the Orthodox church in Avrig, a place where, for several centuries, Romanians and Saxons lived together. Visiting 
the native village of Gheorghe Lazăr in the third decade of the last century, Nicolae Iorga noticed the great artistic value of the church, which is located close to the tomb of Lazăr, the scholar from Avrig, who was a chief founder of Romanian higher education. "With a feeling of natural piousness", confessed the passionate investigator of Romanian history sources, "I came close, during a recent trip .... to the fortress-like church in Avrig. The tower, just like that of Saxon places of worship, is very imposing. On the side towards the road one can observe the year 1795, with Latin marks of which today only the following words may be made out «ab anno ... rev anno». On the door inside, an older date is inscribed: 1792 " 42 .The same Western features, inspired by the architecture of Saxon churches, were also observed by Victor Brătulescu. „Well built, as most churches in the region, (appreciation that, we believe, was addressed indirectly to the craftsmanship of Saxon masons) the church of Avrig has the tower above the narthex and this tower also functions as a belfry. It has a square base and ends with a sharp helmet. A very narrow eave, as the entire eaves of the church are, bounds the top of the tower.

Light enters through four windows with a stone cornice. This cornice, with a bilobate upper side, shows a vertical partition, so as in the case of the same window two smaller panes may be enclosed in the cornice mentioned before" 43

This robust tower, the height of which exceeds by only two or three meters, at the level of the cornice, the height at the ridge of the roof that corresponds to the nave of the church (thus showing how the towers of two other churches, i.e. "St. Paraskevi” from Răşinari and the church of Sadu, had probably looked before being over raised), with bilobed windows of Roman influence, demonstrates its similarity to the shape of the tower of the Lutheran church in the village. It was, as in most cases that we studied, added to the church after the time when the latter was built. The service of consecrating the cornerstone of the church was led by the Greek-Catholic bishop Petru Pavel Aron, who dedicated the church in $1758^{44}$. Though written in an unusual place, namely on the vault of the eastern apse, the text of the inscription brings further clarification as regards the event mentioned above: "This holy and divine church was built from the foundation at the expense of the Romanians of the village in the days of Empress Maria Theresa and a holy cross, brought by priest Lazar, the son of priest Paul, was placed on the right corner

42 Nicolae Iorga, "Biserica din Avrig şi valoarea ei de artă", in: Revista Teologică, Sibiu, XII (8/1922), p. 190.

43 Victor Brătulescu, "Biserici din Transilvania. Biserica din Avrig", in: Omagiu fraților Alexandru şi Ion Lapedatu, Bucureşti 1936, p. 184, 185.

44 G. M. Miron, Biserica greco-catolică, p. 329. 
of the altar, as cornerstone 1755 . Who paid for the painting of the altar vault, for eternal remembrance".

As for the source that inspired the craftsmen from 1792 to 1795 in building the bell tower of the Romanian church, namely the tower of the Saxon church, it was built, along with the basilica, in the Roman times, in the third quarter of the thirteenth century, with the support of the city council of Sibiu, for the community there was too small. Historian Stefan Lupşa wrote about it, but with reference to a more recent stage, when the older church was fortified, that "the rich men from Sibiu built, for the «poor Saxons from Freck», a stone basilica, with a defense tower, on a high place in the middle of the village in $1506^{\prime \prime}$.

A tower, very similar in shape and proportions to that in Avrig, was added at some point in its history of over four centuries, to St. Nicholas' Orthodox church of Porceşti (today Turnu Roşu, Sibiu County). Founded by the Wallachian ruler Matei Basarab, in 1653, the church was originally conceived as similar to the places of worship beyond the mountains ${ }^{46}$. This similitude implied that originally it did not have a bell tower, which is proved by the representation of the ark of the church itself, in the votive scene, painted in 1750 by painter Oprea Mihail Crăciun on the north facade of the monument. This picture also shows the series of subsequent changes brought to the edifice in the years $1827-1828$. It is a resizing by expanding and adding new parts, as well as the change of planimetry by the building of side apses and finally of the bell tower, which was raised above the narthex. In 1940, the author of the first monograph of the church, Andrew Gâlea, brought interesting details about this moment. "The elements added to the church were made by two Saxon masters of Sibiu, Andrei Krämmer and Andrei Hopprich, for the sum of 1,096 florins, plus the feeding of the masters. The materials and the workers were paid for by the parish. The contract was written in German on the $18^{\text {th }}$ of July 1827 and is still preserved in the parish archives. It was signed on the behalf of the parish by the three priests of the church, and in the name of the municipality of the county, by the judge, the county magistrate aid and the headman of the village" 47 .

We should point out here that the same Andreas Krämmer, mason from Sibiu, had also contributed, 1813-1822, to the building of the monumental church with bell tower in the village of Boiţa.

\footnotetext{
45 Şt. Lupşa, "Satul lui Gheorghe Lazăr", p. 43.

46 V. Vătăşianu, Arta în Transilvania, p. 158.

47 Andrei Gâlea, "O ctitorie a lui Matei Basarab în Ardeal (Biserica din comuna Porceşti, jud. Sibiu)”, in: Omagiu Inalt Prea Sfinţiei Sale Dr. Nicolae Bălan Mitropolitul Ardealului, la 20 de ani de arhipăstorire, Sibiu 1940, p. 425.
} 
In the period that followed until the early twentieth century, to almost all existing churches in the villages of Sibiu, west towers were added, these becoming a recognizable architectural feature for the churches of the Romanians in Transylvania. They were built in 1816 at Săliştea Sibiu, for the church of Grui (built in 1742); in 1824, in Arpaşul de Jos (the church dated 1794); in Bungard, prior to 1824 (the church dates from 1689 to 1691); in 1834, in Gura Râului (the church of "St. Paraskeva", dating back to medieval times and improved in 1802); in 1879, in Loamneş (edifice erected in 1800-1810) and in many other places.

Looking at the way Romanian religious architecture of Wallachian inspiration evolved, in the region around Sibiu, in the last half of the eighteenth century and during the century that followed, we found an interesting aspect, namely that in almost every situation records indicate that the bell tower was raised after the building of the church itself, sometimes at a distance of several decades. This aspect may be explained by the additional costs that communities could not afford, at the moment of raising and decorating their churches. The presence of towers in places of worship of the Eastern rite was stimulated by the impressive monumental aspect that, over time, such vertical elements enhanced imprinted the architecture of fortified churches and of the Saxon parish churches, belonging to a community next to whom the Romanians lived. The adoption, by Romanian churches, of forms characteristic of indigenous medieval, Roman-Gothic architecture and later of modern architecture, inspired by the Austrian Baroque, from the Josephine epoch, was a natural phenomenon, because in most situations, when such construction sites were initiated, the craftsmen performers were Saxons from Sibiu. What is truly remarkable in this collaboration between ethnic groups of different confessions, is that the Saxon craftsmen were entrusted with raising not only bell towers in a style they were familiar with, but also with building the churches themselves, which had to remain under the sign of Romanian Post-Byzantine architecture. This is a proof that, in the epoch, there had been some architectural projects aimed at building Romanian churches, which included technical data that could be easily interpreted by craftsmen, but also the experience acquired by those masons in time, resulting from a constant collaboration in the raising of such worship places, with the neighbors of the Eastern rite.

\section{List of illustrations}

Fig. 1 The Orthodox church in Sadu

Fig. 2 „St. Paraskevi” Orthodox church in Răşinari 
Ioan Ovidiu Abrudan

Fig. 3 The Church „Among the Fir-Trees”, Sibiu

Fig. 4 The Church from the Pit, Sibiu

Fig. 5 The Orthodox church in Sibiel

Fig. 6 The Orthodox church in Avrig

Fig. 7 The Lutheran Church in Cisnădie

Fig. 8 „St. Nicholas” Orthodox church in Turnu Roşu

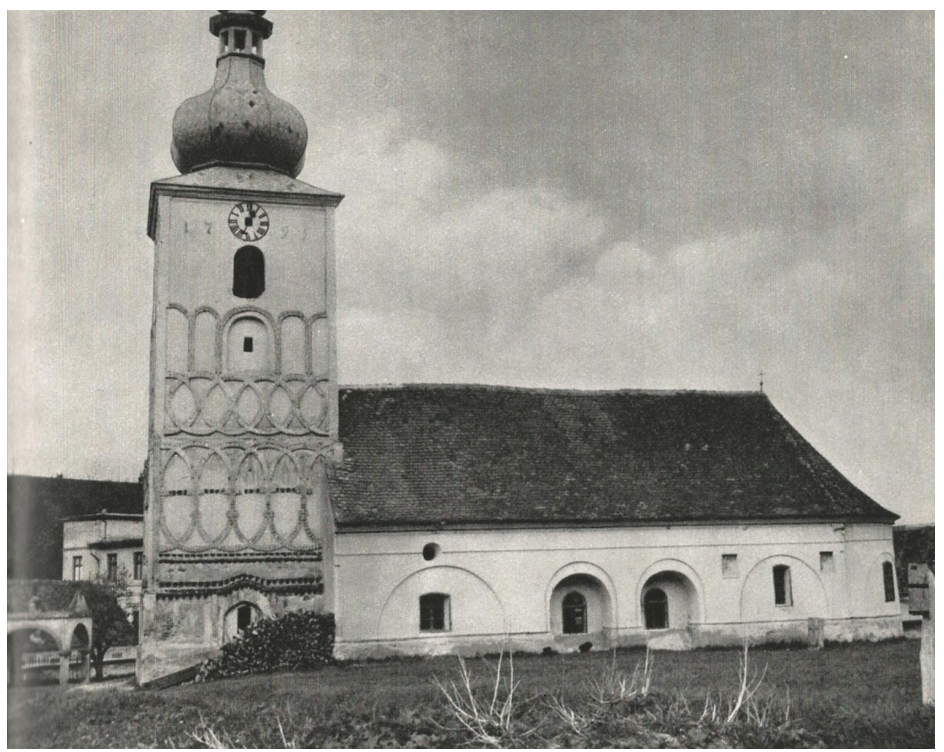

Fig. 1

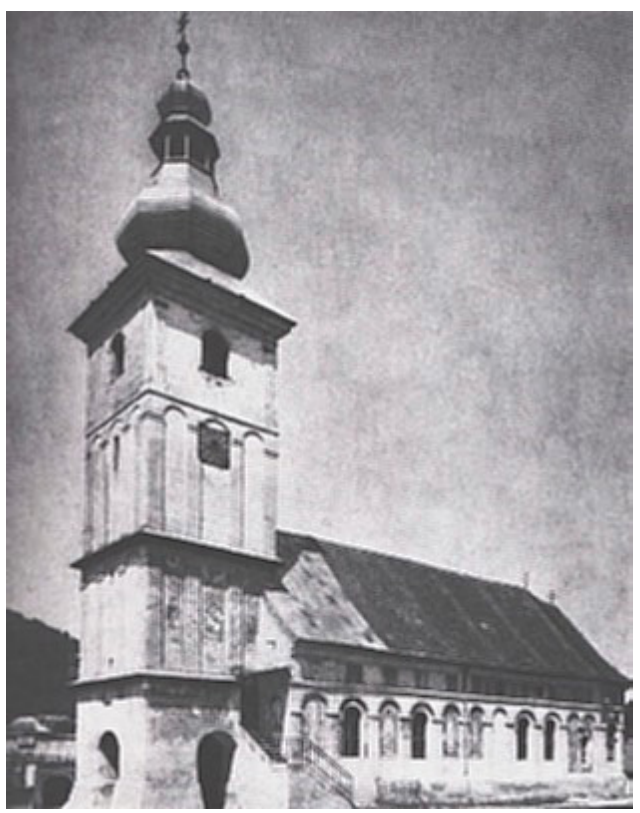

Fig. 2 
The Building of Bell-Towers Added to Romanian Churches

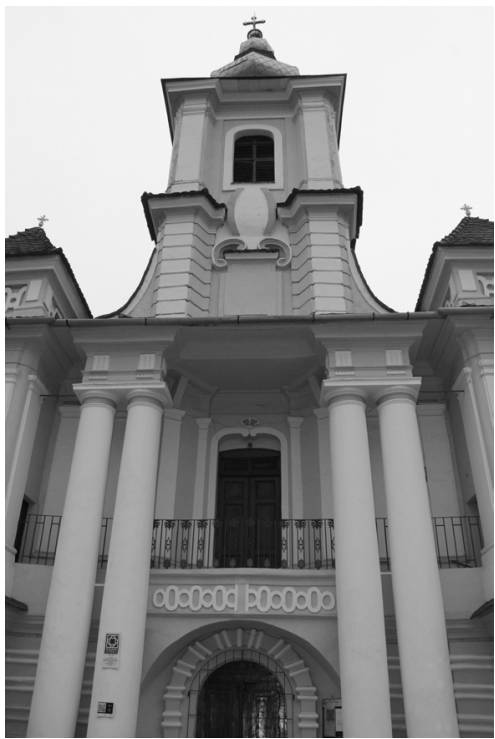

Fig. 3

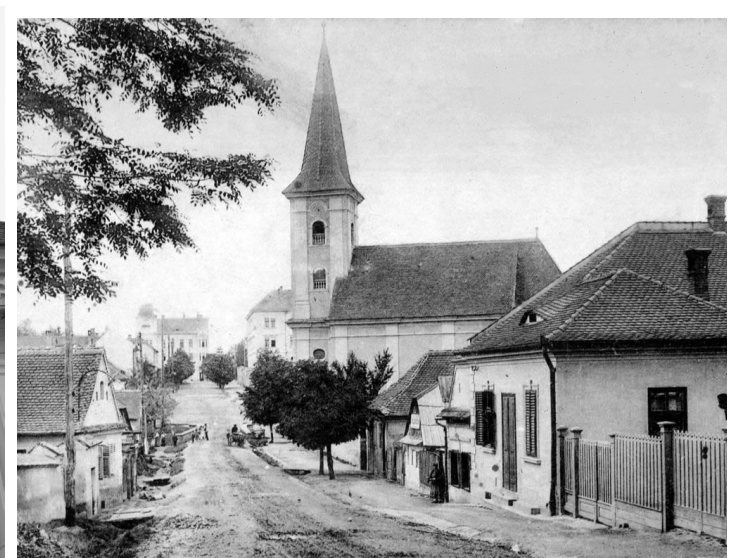

Fig. 4

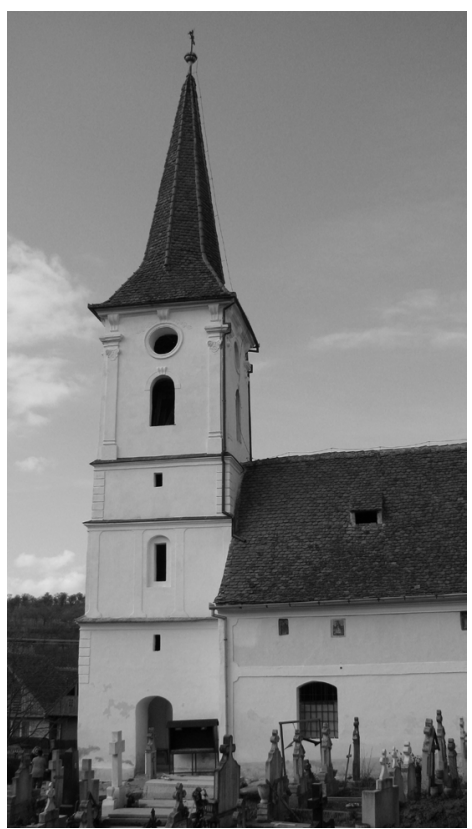

Fig. 5

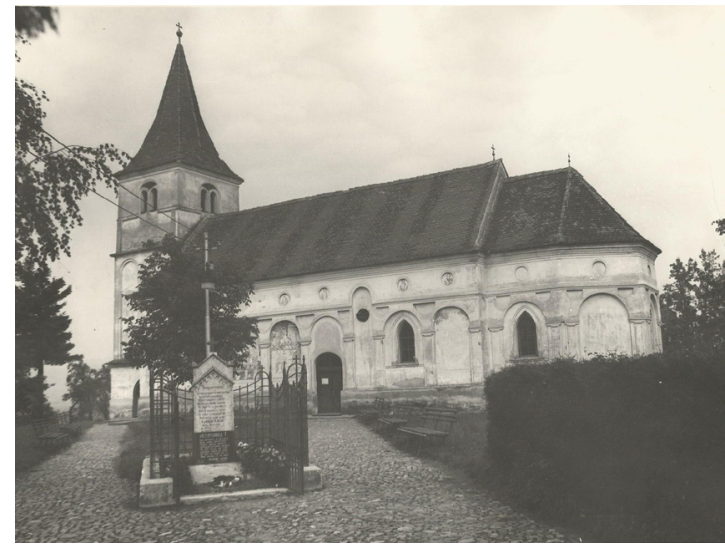

Fig. 6 
Ioan Ovidiu Abrudan

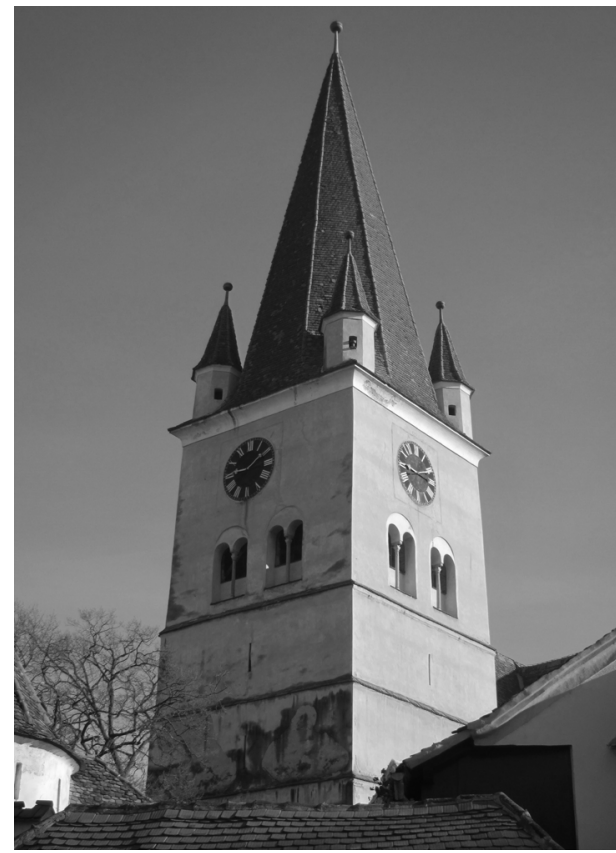

Fig. 7

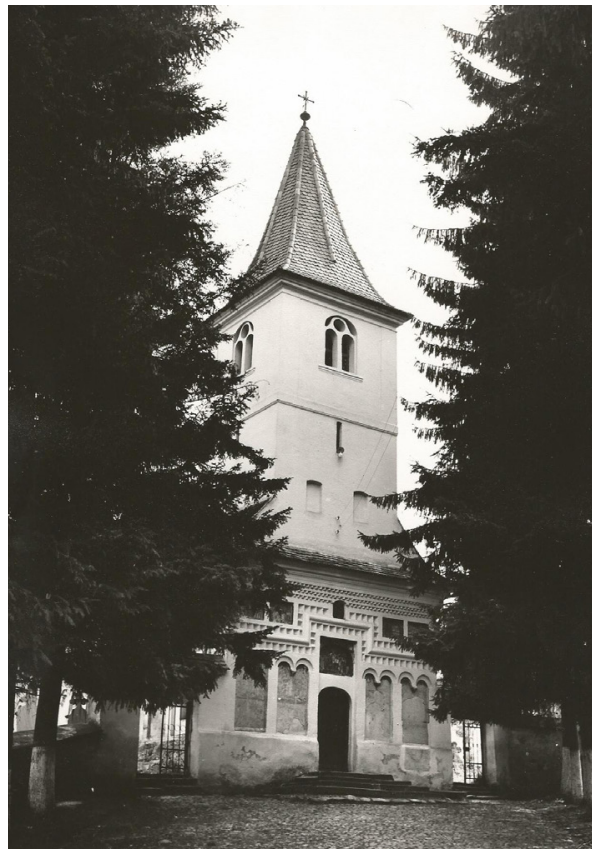

Fig. 8 